\title{
Why Federal Courts Should Be Required to Consider State Sovereign Immunity Sua Sponte
}

\author{
Michelle Lawnert
}

Suppose that a state is sued in its own courts under a provision of federal law. The state, believing that its chances of victory are better in a federal forum, removes the case to federal court. ${ }^{1}$ Unfortunately for the state, it made the wrong choice. After the state loses in federal court, the state appeals. Among its arguments, the state adds a new defense: Eleventh Amendment immunity.

The Supreme Court has held repeatedly that a state may raise Eleventh Amendment immunity for the first time on appeal. ${ }^{2}$ Recently, Justice Kennedy characterized the Court's approval of belated assertions of Eleventh Amendment immunity as "allow[ing] States to proceed to judgment without facing any real risk of adverse consequences." Because a state may litigate the merits of a case without forfeiting its Eleventh Amendment immunity, it can await a federal court's decision before deciding

$\dagger$ B.A. 1994, Georgetown University; J.D. Candidate 2000, The University of Chicago.

${ }_{1}$ Removal provides defendants with an opportunity to invoke federal jurisdiction even if a plaintiff originally files the suit in state court. The basic removal provision, 28 USC $\S 1441$ (a) (1994), provides:

Except as otherwise expressly provided by Act of Congress, any civil action brought in a State court of which the district courts of the United States have original jurisdiction, may be removed by the defendant or the defendants, to the district court of the United States for the district and division embracing the place where such action is pending.

Generally, a defendant can remove actions over which the federal district courts have original jurisdiction. There are two main categories of original jurisdiction. The first category, federal question jurisdiction, includes cases "arising under the Constitution, laws, or treaties of the United States." 28 USC § 1331 (1994). The second category, diversity jurisdiction, includes cases in which the matter in controversy is greater than $\$ 75,000$ and the controversy is between citizens of different states. 28 USCA $\S 1332$ (a) (1993 \& Supp 1998). But see Mitchell N. Berman, Note, Removal and the Eleventh Amendment: The Case for District Court Remand Discretion to Avoid a Bifurcated Suit, 92 Mich L Rev 683, 695-96 (1993) (arguing that federal diversity jurisdiction cannot lie over a case to which a state is a party).

2 See, for example, Pennhurst State School and Hospital $v$ Halderman, 465 US 89, 99 n 8 (1984); Edelman v Jordan, 415 US 651, 677-78 (1974); Ford Motor Co v Department of Treasury of Indiana, 323 US 459, 466-67 (1945).

${ }^{3}$ Wisconsin Department of Corrections v Schacht, 118 S Ct 2047, 2055 (1998) (Kennedy concurring). 
whether to object to the court's jurisdiction. If the decision is unfavorable to the state, the state can appeal, assert Eleventh Amendment immunity, and have the judgment vacated on the ground that the federal court lacked jurisdiction over the state. On the other hand, if the state prevails, it can take advantage of the claim preclusive effect of its victory. By permitting assertions of Eleventh Amendment immunity for the first time on appeal, the Supreme Court has conferred upon states "an unfair advantage," enabling states to use Eleventh Amendment immunity as both a sword and a shield.

The Eleventh Amendment clearly protects states from suit in federal court. But when a state defendant removes a case to federal court only to contend that no relief can be granted, Eleventh Amendment immunity is transformed into a sword. ${ }^{5}$ This Comment examines Justice Kennedy's proposed solution to this problem of strategic behavior by states, which is to construe a state's removal of a case to federal court as a waiver of its Eleventh Amendment immunity. After concluding that Justice Kennedy's proposal would afford inadequate protection to state sovereign immunity, the Comment argues that the strategic behavior problem should instead be solved by a rule requiring federal district courts to consider sovereign immunity sua sponte in any case that appears to present the issue.

Part I of this Comment provides a brief introduction to the Eleventh Amendment, explaining how, in most cases, the Supreme Court has appropriately safeguarded state sovereignty while balancing it against the need for state accountability. Part II explains that to the extent current law enables states to use the Eleventh Amendment as a tool of strategic litigation, it undermines state accountability without any corresponding benefit. Permitting belated assertions of Eleventh Amendment immunity forces appellate courts to vacate judgments at a late stage of litigation, rendering federal district court decisions moot and

1. Id.

- In Gorka v Sullivan, 82 F3d 772 (7th Cir 1996), the Seventh Circuit characterized such legal maneuvering by a state defendant as permitting the doctrine of sovereign immunity to "operate as a sword as well as a shield." Id at 773. In Gorka, Medicaid recipients brought a suit alleging both federal and state law claims against Indiana officials after Indiana announced plans to reduce reimbursement rates for transportation services. After the defendants removed the case to federal court, the plaintiffs filed a motion to remand the suit to state court, arguing that complete relief would be barred because of the defendants' assertion of sovereign immunity. The district court retained jurisdiction over the entire suit, ruled against the plaintiffs on the merits of the federal law claims, and remanded the state law claims. On appeal, the Seventh Circuit vacated the district court's decision and ordered the entire case remanded to state court, holding that the Eleventh Amendment barred federal court jurisdiction over the state. Id at 774-75. 
thereby diminishing state accountability in federal courts. Part III concludes that requiring federal courts to raise Eleventh Amendment immunity sua sponte would largely eliminate the unfair advantage that states currently have because federal courts would only hear cases against states if they have waived their immunity. ${ }^{6}$ Because the sua sponte rule would safeguard state sovereign immunity while providing private plaintiffs with a proper forum in which to litigate the merits of a case, this solution would better balance the values of state sovereignty and state accountability than Justice Kennedy's proposed solution.

\section{THE ELEVENTH AMENDMENT}

The Eleventh Amendment provides: "The Judicial power of the United States shall not be construed to extend to any suit in law or equity, commenced or prosecuted against one of the United States by Citizens of another State, or by Citizens or Subjects of any Foreign State." The Supreme Court often characterizes the Eleventh Amendment as a constitutional affirmation of the broad principle of state sovereign immunity. ${ }^{8}$ Accordingly, the Court interprets it as a blanket restriction on suits against unconsenting states in federal court. Moreover, the Court routinely invokes the Eleventh Amendment to safeguard the values of federalism, ${ }^{9}$ as-

6 Similarly, federal courts would hear suits against state defendants if Congress abrogated state sovereign immunity pursuant to Congress's enforcement power under Section Five of the Fourteenth Amendment. See Part I.B.

US Const, Amend XI.

- See, for example, Seminole Tribe of Florida v Florida, 517 US 44, 54 (1996); Welch $v$ Texas Department of Highways and Public Transportation, 483 US 468, 486 (1987) (noting that the Supreme Court has "firmly established that the Eleventh Amendment embodies a broad constitutional principle of sovereign immunity"). It is important to note, however, that many scholars disagree with the Supreme Court's interpretation of the Eleventh Amendment as an affirmation of states' sovereign immunity from suit in federal court. See, for example, Vicki C. Jackson, The Supreme Court, the Eleventh Amendment, and State Sovereign Immunity, 98 Yale L J 1, 44-49 (1988) (concluding that the Eleventh Amendment does not supply constitutional immunity for states as to claims arising under federal law); John J. Gibbons, The Eleventh Amendment and State Sovereign Immunity: A Reinterpretation, 83 Colum L Rev 1889, 2004 (1983) (concluding that the Eleventh Amendment limits only the diversity jurisdiction of the federal courts, thus permitting federal court jurisdiction over suits against states arising under federal law). See also Seminole Tribe, 517 US at 110 (Souter dissenting) (arguing that "[t]he history and structure of the Eleventh Amendment convincingly show that it reaches only to suits subject to federal jurisdiction exclusively under the Citizen-State Diversity Clauses").

9 Federalism not only safeguards state sovereignty but also ensures political accountability through local participation in government, permits governmental experimentation with the states serving as "laboratories," and protects individuals against an omnipotent federal government. See John R. D'Angelo, Note, Reconciling Federalism and Individual Rights: The Burger Court's Treatment of the Eleventh and Fourteenth Amendments, $68 \mathrm{Va}$ L Rev 865, 865-66 n 4 (1982). The Eleventh Amendment serves some of the values of fed- 
serting that "the doctrine of sovereign immunity plays a vital role in our federal system." However, scholars have criticized the Court's Eleventh Amendment jurisprudence for failing to protect the competing values of federalism equally. In particular, the Court's construction of the Eleventh Amendment has been criticized for excessively favoring state sovereignty at the expense of state accountability. ${ }^{11}$ This Part argues that although Eleventh Amendment jurisprudence protects state sovereignty more than it ensures state accountability, the Supreme Court's attempts to reconcile these competing interests nevertheless comport with the balance contemplated by the Framers.

\section{A. The Eleventh Amendment and State Sovereignty}

The passage of the Eleventh Amendment marked the first successful attempt to overrule a Supreme Court decision by constitutional amendment. In Chisholm $v$ Georgia, ${ }^{12}$ the Supreme Court upheld federal jurisdiction over an action initiated by a South Carolina resident to recover money owed by the State of Georgia. Georgia argued that sovereign immunity protected it from suit in federal court despite the fact that Article III explicitly extends federal judicial power to "controversies . . . between a State and Citizens of another State." ${ }^{\prime 3}$ The Supreme Court adhered to the plain language of Article III and denied Georgia sovereign immunity from suit in federal court. The Chisholm decision "created such a shock of surprise throughout the country that, at the first meeting of Congress thereafter, the Eleventh Amendment ... was almost unanimously proposed, and was in due course adopted by the legislatures of the States." ${ }^{14}$ In light of the history surrounding the ratification of the Eleventh Amendment, the Supreme Court has since "understood the Eleventh Amendment to stand not so much for what it says, but for the presupposition of our constitutional structure which it confirms: that the States entered the federal system with their sovereignty intact; that the judicial authority in Article III is limited by this sovereignty; and that a State will therefore not be subject to suit in federal court unless it has consented to suit, either expressly or in the 'plan of the convention."'15

eralism by recognizing state immunity and by protecting a state's treasury. Id.

${ }^{10}$ Welch, 483 US at 486-87.

"See note 66.

${ }^{12} 2$ US (2 Dall) 419 (1793).

${ }^{13}$ Id at 431, citing US Const, Art III, § 2, cl 1 .

"Hans v Louisiana, 134 US 1, 11 (1890).

${ }^{15}$ Blatchford $v$ Native Village of Noatak, 501 US 775, 779 (1991) (citations omitted). 
In an effort to safeguard states' sovereignty, the Supreme Court has characterized the Eleventh Amendment as a reassertion of the immunity from suit held by states at common law. ${ }^{16}$ The states originally enjoyed sovereign immunity from all suits, whether initiated by their own citizens, by citizens of another state, or by citizens of a foreign country. ${ }^{17}$ At common law, "[t]he suability of a State without its consent was a thing unknown to the law,"18 and thus, "the fundamental principle of sovereign immunity limits the grant of judicial authority in Art. III."19 The Supreme Court has applied this characterization of the Eleventh Amendment expansively to guard state sovereignty and to limit the reach of federal jurisdiction.

The Supreme Court's Eleventh Amendment jurisprudence demonstrates a strong commitment to the principle of state sovereignty. In Hans $v$ Louisiana, ${ }^{20}$ the Supreme Court held that states were immune from suits initiated by their own citizens, ${ }^{21}$ even though the text of the Eleventh Amendment merely prohibits suits against a state "by Citizens of another State, or by Citizens or Subjects of any Foreign State."22 The Court held that it would be "anomalous" to interpret the Constitution as guarding states' sovereign immunity from suits by citizens of another state while allowing suits against a state by its own citizens. ${ }^{23}$ It therefore held that sovereign immunity was protected by an implicit limitation on the federal judicial power under Article III. Similarly, in Ex parte New York, ${ }^{24}$ the Supreme Court extended Eleventh Amendment immunity to insulate states from admiralty

The phrase "in the plan of the convention" refers to the notion that in ratifying the Constitution, each of the states may have given up some sovereignty as a condition of entering the Union.

16 See Hans, 134 US at 15-16. See also Seminole Tribe, 517 US at 54 (affirming that "each State is a sovereign entity in our federal system ... [and] [i]t is inherent in the nature of sovereignty not to be amenable to the suit of an individual without its consent") (internal quotation marks omitted) (collecting cases). Nevertheless, a great deal of academic scholarship questions whether governments were immune from suit in court at common law. See, for example, Gibbons, 83 Colum L Rev at 1913-14 (cited in note 8) (concluding that "the evidence upon which the [Supreme] Court has relied in justification for the position that the eleventh amendment restored the original understanding about state sovereign immunity is insufficient to support that position").

${ }^{17}$ Erwin Chemerinsky, Federal Jurisdiction $\$ 7.3$ at 378 (Little, Brown 2d ed 1994).

is Hans, 134 US at 16.

19 Pennhurst State School and Hospital v Halderman, 465 US 89, 98 (1984). See also Welch, 483 US at 472; Atascadero State Hospital v Scanlon, 473 US 234, 238 (1985), both quoting Pennhurst, 465 US at 98.

s 134 US 1 (1890).

21 Id at 20.

22 US Const, Amend XI.

${ }^{2}$ Hans, 134 US at 10-11.

256 US 490 (1921). 
suits $^{25}$ even though the Amendment by its terms applies only to suits "in law or equity." Finally, in Principality of Monaco $v$ Mississippi, ${ }^{27}$ the Court relied on the sovereignty principle to hold that the Eleventh Amendment barred federal court jurisdiction over suits initiated by foreign nations against a state ${ }^{23}$ despite the fact that the terms of the Eleventh Amendment merely prohibit suits by "Citizens or Subjects of any Foreign State." As these decisions demonstrate, the Court often invokes the sovereignty principle to move beyond the literal terms of the Eleventh Amendment in order to insulate the states from federal jurisdiction.

The sovereignty principle not only facilitates an expansive interpretation of the Eleventh Amendment, but also affords states certain rights as litigants. Most importantly, the Supreme Court has recognized that the principle of sovereign immunity permits states to waive their Eleventh Amendment immunity and consent to suit in federal court, for "[1]ike any sovereignty, a State may voluntarily consent to be sued." ${ }^{30}$ To effectuate a valid waiver of immunity the Supreme Court requires "an unequivocal indication that the State intends to consent to federal jurisdiction that otherwise would be barred by the Eleventh Amendment."31 In most cases, the alleged waiver of immunity is found insufficient to constitute consent to suit in federal court. For example, the Supreme Court has held that, absent an explicit legislative grant of authority, a state's attorney general may not waive the state's Eleventh Amendment immunity. ${ }^{32}$ Additionally, the Supreme Court has held that "[t]he mere fact that a State participates in a program through which the Federal Government provides assistance for the operation by the State of a system of public aid is not sufficient to establish consent on the part of the

25 Id at 497-98.

${ }^{2}$ US Const, Amend XI. The Supreme Court has held that Article III establishes suits in admiralty as a class of cases distinct from suits in law and equity. See Romero $v$ International Terminal Operating Co, 358 US 354, 364-67 (1959); The American Insurance Co $v$ Canter, 26 US (1 Pet) 511, 544-45 (1828).

27292 US 313 (1934).

23 Id at 322-29.

2 US Const, Amend XI.

${ }^{30}$ Ashton v Cameron County Water Improvement District, 298 US 513, 531 (1936). See also Welch, 483 US at 473 "If a State waives its immunity and consents to suit in federal court, the suit is not barred by the Eleventh Amendment."); Gunter $v$ Atlantic Coast Line Railroad Co, 200 US 273, 284 (1906) ("Although a state may not be sued without its consent, such immunity is a privilege which may be waived."); Clark $v$ Barnard, 108 US 436, 447 (1883) (stating that Eleventh Amendment immunity "is a personal privilege which [a state] may waive at pleasure").

"Atascadero, 473 US at $238 \mathrm{n} 1$.

32 Ford Motor Co $v$ Department of Treasury of Indiana, 323 US 459, 468 (1945). 
State to be sued in the federal courts. ${ }^{.33}$ A state does not waive its Eleventh Amendment immunity from suit in federal court merely by waiving immunity from suit in its own state $\operatorname{courts}^{34}$ or through a state statute authorizing the state to be sued "in any court of competent jurisdiction." 35 The Court's reluctance to find valid waiver demonstrates its commitment to safeguarding state sovereign immunity as embodied in the Eleventh Amendment, ${ }^{36}$ for "[c]onstructive consent is not a doctrine commonly associated with the surrender of constitutional rights." 37

\section{B. The Eleventh Amendment and State Accountability}

The principle of sovereign immunity is in tension with the principle that the law generally will provide a remedy for rights violated by a state. $^{38}$ Furthermore, construing the Eleventh Amendment as a broad prohibition on suits against states in federal court divests the courts of an important mechanism by which to ensure state compliance with federal laws. Consequently, the Supreme Court has acknowledged that states' Eleventh Amendment immunity is not absolute.

The Supreme Court began to restrict the application of the Eleventh Amendment by allowing plaintiffs to sue state officers. In Ex parte Young, ${ }^{39}$ the Court held that a state officer executing an unconstitutional law was to be regarded as acting ultra vires. ${ }^{40}$ Accordingly, relief against the officer named as defendant was not to be considered relief against the state and thus was not barred by the Eleventh Amendment. ${ }^{41}$ Similarly, in Fitzpatrick $v$ Bitzer, $^{42}$ the Court held that Congress may use its enforcement authority under the Fourteenth Amendment to abrogate states'

${ }^{3}$ Edelman $v$ Jordan, 415 US 651, 673 (1974). See also Atascadero, 473 US at 246-47 (holding that "the mere receipt of federal funds cannot establish that a State has consented to suit in federal court").

* Pennhurst, 465 US at 99 n 9. Accord Welch, 483 US at 473-74.

35 Kennecott Copper Corp v State Tax Commission, 327 US 573, 578 (1946).

${ }^{36}$ Scholars often contest the view of the Eleventh Amendment as an embodiment of sovereign immunity. See note 8 . Nonetheless, the Supreme Court interprets the Eleventh Amendment as an affirmation of sovereign immunity.

${ }^{37}$ Edelman, 415 US at 673.

36 See Marbury $v$ Madison, 5 US (1 Cranch) 137, 162 (1803) ("The very essence of civil liberty certainly consists in the right of every individual to claim the protection of the laws, whenever he receives an injury.").

39209 US 123 (1908).

* Id at 159-60.

4I Id at 157-60.

427 US 445 (1976). 
Eleventh Amendment immunity and permit suits for damages against states. ${ }^{43}$

Although the Court has made some efforts to restrict the scope of the Eleventh Amendment, it interprets these exceptions narrowly. For example, in Edelman $v$ Jordan ${ }^{44}$ the Court limited the availability of relief in Ex parte Young actions to prospective relief, such as an injunction..$^{45}$ Retroactive relief, such as a monetary award for past wrongdoing, is barred because payment would come from the state treasury. ${ }^{46}$ Similarly, in Atascadero State Hospital $v$ Scanlon, ${ }^{47}$ the Court limited the scope of the congressional abrogation doctrine, holding that "Congress may abrogate the States' constitutionally secured immunity from suit in federal court only by making its intention unmistakably clear in the language of the statute."48 The Court reasoned that this clear statement rule was necessary to ensure that federal courts did not subject states to suits when Congress did not intend for the states' immunity to be abrogated. ${ }^{49}$ Several years later, in Dellmuth $v$ Muth,$^{50}$ the Court demonstrated the restrictive nature of the clear statement rule by noting that "evidence of congressional intent must be both unequivocal and textual. . . . Legislative history generally will be irrelevant." 51

The Court further limited the congressional abrogation doctrine in Seminole Tribe of Florida $v$ Florida. ${ }^{52}$ Just seven years after the Court had ruled in Pennsylvania $v$ Union Gas $\mathrm{Co}^{53}$ that Congress may override the Eleventh Amendment when it acts pursuant to any Article I power, ${ }^{54}$ the Court reversed itself. In Seminole Tribe, the Supreme Court limited Congress's power to abrogate states' Eleventh Amendment immunity to laws enacted pursuant to Section Five of the Fourteenth Amendment. ${ }^{55}$ The Court reasoned, "The Eleventh Amendment restricts the judicial power under Article III, and Article I cannot be used to circum-

${ }^{43}$ Id at 456.

11 415 US 651 (1974).

t5 Id at 664-65.

${ }^{45}$ Id.

4743 US 234 (1985).

${ }^{48}$ Id at 242.

49 Id at 242-43.

${ }^{80} 491$ US 223 (1989).

it Id at 230 .

52517 US 44 (1996).

491 US 1 (1989).

${ }^{51}$ Id at 23 (holding that Congress may abrogate states' Eleventh Amendment immunity when it acts pursuant to the Commerce Clause power so long as the federal statute abrogating immunity expressly authorizes suits against states in federal court).

s 517 US at 59-73. 
vent the constitutional limitations placed upon federal jurisdiction." ${ }^{\text {"56 }}$ Because of the strength with which the Court reaffirmed the principle that the Eleventh Amendment serves as a bar to federal jurisdiction, the decision in Seminole Tribe is a noteworthy limit on the ability to hold state governments accountable in federal court.

\section{The Balance Struck by the Supreme Court}

The Supreme Court's Eleventh Amendment jurisprudence undoubtedly demonstrates a greater commitment to protecting state sovereign immunity than to ensuring state accountability in federal court. ${ }^{57}$ This commitment seems consistent with the intent of the Framers of the Eleventh Amendment who, by phrasing the Amendment in such broad and absolute terms, evinced their intent that sovereignty ought to be paramount over accountability. Eleventh Amendment doctrine has developed on the premise, based on the history of the Amendment's ratification, that the states entered the Union "with their sovereignty intact." cordingly, states' sovereignty limits the reach of federal judicial power such that private plaintiffs cannot sue a state in federal court unless the state has consented-either explicitly or "in the plan of the convention." 59 In this manner, the Eleventh Amendment is said to reinstate the general view held before Chisholmthat a state could not be sued without its consent. ${ }^{60}$

Moreover, employing the Eleventh Amendment to safeguard state sovereignty may be justified given the absence of other constitutional provisions that explicitly preserve the federal system. As the Supreme Court has noted:

[O]ur Eleventh Amendment doctrine is necessary to support the view of the federal system held by the Framers of the Constitution. The Framers believed that the States played a vital role in our system and that strong state governments

${ }^{36}$ Id at 72-73.

${ }^{57}$ See Erwin Chemerinsky, Formalism and Functionalism in Federalism Analysis, 13 Ga St U L Rev 959, 983 (1997). See also Jackson, 98 Yale $L J$ at 72-104 (cited in note 8).

ss Blatchford, 501 US at 779-82 (finding "no compelling evidence that the Founders thought such a surrender [of sovereignty] inherent in the constitutional compact").

${ }^{\text {so }}$ Monaco, 292 US at 323, quoting Federalist 81 (Hamilton).

${ }^{\infty}$ See Hans, 134 US at 15-16 ("The truth is, that the cognizance of suits and actions unknown to the law, and forbidden by the law, was not contemplated by the Constitution when establishing the judicial power of the United States. . . . The suability of a State without its consent was a thing unknown to the law."). See also Charles Warren, I The Supreme Court in United States History 91-96 (Little, Brown 1923) (presenting contemporary views that states enjoyed common law immunity prior to the Supreme Court's decision in Chisholm). 
were essential to serve as a "counterpoise" to the power of the Federal Government. ${ }^{61}$

The fundamental principles of federalism thus compel the Court to protect state sovereignty. Eleventh Amendment jurisprudence appropriately reflects this goal.

As a safeguard of state sovereignty, the Eleventh Amendment most directly serves to prevent the subjugation of state governments by the federal government. Empowering a federal court to pass judgment on an unconsenting state is an affront to the dignity of the state as a sovereign and a threat to the state's treasury. As the Supreme Court recently reaffirmed, "The Eleventh Amendment does not exist solely in order to 'preven[t] federal-court judgments that must be paid out of a State's treasury'; it also serves to avoid 'the indignity of subjecting a State to the coercive process of judicial tribunals at the instance of private parties." 62 Thus, to bind unwilling states to the judgments of federal courts would aggrandize the power of the federal government at the expense of state governments.

The ratification of the Constitution largely depended upon the Framers' ability to dispel the fear that the Constitution would empower "the Federal Judiciary to summon a State as defendant and to adjudicate its rights and liabilities." 63 To this end, Alexander Hamilton wrote:

It is inherent in the nature of sovereignty, not to be amenable to the suit of an individual without its consent. This is the general sense and the general practice of mankind; and the exemption, as one of the attributes of sovereignty, is now enjoyed by the government of every state in the union. . . . To what purpose would it be to authorise suits against states, for the debts they owe? How could recoveries be enforced? It is evident that it could not be done without waging war against the contracting state; and to ascribe to the federal courts, by mere implication, and in destruction of a preexisting right of the state governments, a power which would

${ }^{61}$ Atascadero, 473 US at $238 \mathrm{n}$ 2, citing Federalist 17 (Hamilton), in Jacob E. Cooke, ed, The Federalist 105, 107-08 (Wesleyan 1961), and Federalist 46 (Madison), in Cooke, ed, The Federalist 315, 316-17.

${ }_{62}$ Seminole Tribe, 517 US at 58, citing Hess $v$ Port Authority Trans-Hudson Corp, 513 US 30, 48 (1994), and Puerto Rico Aqueduct and Sewer Authority v Metcalf \& Eddy, Inc, 506 US 139, 146 (1993) (citations omitted).

${ }^{\infty}$ Warren, 1 The Supreme Court in United States History at 91 (cited in note 60). 
involve such a consequence, would be altogether forced and unwarrantable. ${ }^{64}$

The Supreme Court's Eleventh Amendment jurisprudence appropriately reflects the problems "inherent in making one sovereign appear against its will in the courts of the other." ${ }^{.5}$ Thus, the Court's jurisprudence manifests an acute awareness of the essential role that the Eleventh Amendment plays in the preservation of our federal system.

Because the Supreme Court's jurisprudence so carefully guards state sovereignty, it has been criticized for failing to ensure state compliance with federal laws. ${ }^{66}$ To some extent, the Court's ostensible disregard for the value of state accountability may reflect its awareness of other mechanisms that adequately ensure state compliance with federal laws. For example, the Eleventh Amendment does not prohibit the Federal Government itself from suing states in federal court in order to enforce substantive federal laws. ${ }^{67}$ Similarly, the Eleventh Amendment does not bar state courts from adjudicating some claims against states that arise under federal law. ${ }^{68}$ Nor does the Eleventh Amendment

4. Federalist 81 (Hamilton), in Cooke, ed, The Federalist 541, 548-49 (cited in note 61).

- Employees $v$ Department of Public Health and Welfare of Missouri, 411 US 279, 294 (1973). See also Welch, 483 US at 486.

${ }^{\circ}$ Generally, these scholars argue that the Eleventh Amendment was enacted to protect states from diversity suits only, leaving federal courts' jurisdiction over cases arising under federal or constitutional law untouched. According to the "diversity theory," the Eleventh Amendment was adopted solely to overrule Chisholm v Georgia, 2 US (2 Dall) 419 , in which the Supreme Court upheld federal diversity jurisdiction over an action initiated by a South Carolina resident to recover money owed by the State of Georgia. Accordingly, because Chisholm only involved a controversy "between a State and Citizens of another State," US Const, Art III, $\S 2, \mathrm{cl} 1$, the Eleventh Amendment only provides state sovereign immunity in suits based on diversity of citizenship. See James E. Pfander, History and State Suability: An "Explanatory" Account of the Eleventh Amendment, 83 Cornell L Rev 1269, 1323-52 (1998); Jackson, 98 Yale L J at 3-13, 44-51 (cited in note 8); Akhil Reed Amar, Of Sovereignty and Federalism, 96 Yale L J 1425, 1473-92 (1987); Gibbons, 83 Colum $L$ Rev at 1934-38 (cited in note 8). Scholars endorsing the diversity theory argue that because of the Supreme Court's misinterpretation of the Eleventh Amendment, the Courts jurisprudence fails both to ensure state compliance with federal laws and to hold state governments accountable through actions in federal court. See, for example, Chemerinsky, $13 \mathrm{Ga}$ St U L Rev at 968-69 (cited in note 57); Jackson, 98 Yale L J at 3 (cited in note 8).

"r Seminole Tribe, 517 US at 71 n 14.

68 The Supreme Court has affirmed the adequacy of state courts as tribunals for the adjudication of cases arising under federal laws. See Idaho $v$ Coeur d'Alene Tribe of Idaho, 117 S Ct 2028, 2037 (1997) ("It would be error coupled with irony were we to bypass the Eleventh Amendment, which enacts a scheme solicitous of the States, on the sole rationale that state courts are inadequate to enforce and interpret federal rights in every case."); Atascadero, 473 US at $238 \mathrm{n} 2$ ("It denigrates the judges who serve on the state courts to suggest that they will not enforce the supreme law of the land."). See also Employees, 411 US at 298 (Marshall concurring) (noting that "since federal law stands as the supreme law 
prohibit suits against state officials for violations of federal law. ${ }^{69}$ Finally, the Eleventh Amendment does not prevent the Supreme Court from reviewing state court decisions involving claims against the states. ${ }^{70}$

Furthermore, as the Constitution does not mandate the establishment of lower federal courts at all, the assertion that state compliance with federal laws depends upon the availability of a federal forum in which to adjudicate the merits of a case is untenable. ${ }^{71}$ Thus, "[t]he issue [concerning the Eleventh Amendment] is not the general immunity of the States from private suit-a question of the common law-but merely the susceptibility of the States to suit before federal tribunals."

\section{The Eleventh AMENDMENT AS A SwORD}

To the extent that the Eleventh Amendment shields state sovereign immunity, it serves the goal of protecting the vital role of the states in our federal system. However, a largely unexplored wrinkle in the Supreme Court's Eleventh Amendment jurisprudence currently permits states to use the Amendment as both a sword and a shield under certain circumstances. Justice Kennedy's concurring opinion in Wisconsin Department of Corrections $v$ Schacht $t^{73}$ demonstrates the ease with which states may use the Eleventh Amendment as a tool of strategic litigation. Justice Kennedy calls for a modification in the Court's jurisprudence to prevent the states from "gaining an unfair advantage."74 This Part describes the "unfair advantage" enjoyed by states that arises from the Supreme Court's Eleventh Amendment jurispru-

of the land, the State's courts are obliged to enforce it, even if it conflicts with state policy"). However, the Eleventh Amendment gives states immunity from suits in state court arising under federal law enacted pursuant to Congress's Article I powers. Alden v Maine, 119 S Ct 2240, 2246 (1999).

${ }^{\infty}$ Ex parte Young, 209 US at 157-60.

${ }^{70}$ See, for example, Bacchus Imports, Ltd v Dias, 468 US 263 (1984); Thomas v Review Board of Indiana Employment Security Division, 450 US 707 (1981); Cohens v Virginia, 19 US (6 Wheat) 264, 383 (1821). For an excellent discussion of Supreme Court review of state court decisions involving claims against the states, see Jackson, 98 Yale $\mathrm{L} J$ at 13-15, $14 \mathrm{n} 59$ (cited in note 8).

${ }^{71}$ Article III, Section 1 of the U.S. Constitution states: "The judicial Power of the United States, shall be vested in one supreme Court, and in such inferior Courts as the Congress may from time to time ordain and establish" (emphasis added).

${ }_{72}$ Employees, 411 US at 293-94. Elsewhere, the Supreme Court has stated: "That States are not liable in [all] circumstances is a necessary consequence of their role in a system of dual sovereignties. Although the dissent denies that sovereign immunity is 'required by the structure of the federal system,' the principle has been deeply embedded in our federal system from its inception." Welch, 483 US at 488 (citations omitted).

${ }^{73} 524$ US 381, 118 S Ct 2047 (1998).

" $118 \mathrm{~S} \mathrm{Ct}$ at 2055 (Kennedy concurring). 
dence and concludes that a modification in this jurisprudence could remedy the unfair advantage conferred upon states and, ultimately, generate a better balance between state accountability and state sovereignty than currently exists.

\section{A. Wisconsin Department of Corrections $v$ Schacht}

In Schacht, the Supreme Court considered whether the presence of some claims barred by the Eleventh Amendment destroys federal court jurisdiction in an otherwise removable case. Schacht, a prison guard, filed a suit against the Wisconsin Department of Corrections and several of its employees, in both their "personal" and "official" capacity, alleging that his dismissal violated the United States Constitution and federal civil rights laws. ${ }^{75}$ The defendants removed the case to federal court and then filed an answer asserting that the Eleventh Amendment barred the claims against the Department and its employees in their official capacities. The district court dismissed the claims against the Department and its employees in their official capacities, and granted the defendants' motion for summary judgment on the personal capacity claims. ${ }^{76}$ On appeal, the Seventh Circuit determined that removal had been improper because the presence of even one claim subject to the Eleventh Amendment bar deprived the federal courts of jurisdiction over the entire case. ${ }^{77}$ The Supreme Court reversed, concluding that

A State's proper assertion of an Eleventh Amendment bar after removal means that the federal court cannot hear the barred claim. But that circumstance does not destroy removal jurisdiction over the remaining [non-barred] claims in the case before us. A federal court can proceed to hear those other claims, and the District Court did not err in doing so. ${ }^{78}$

Justice Kennedy joined in the Court's opinion, but noted that the Court had "neither reached nor considered the argument that, by giving its express consent to removal of the case from state court, [the state] waived its Eleventh Amendment immunity." 79

${ }^{75}$ Id at 2050 (majority opinion). The suit was brought under 42 USC $\S 1983$, which is the basic federal civil rights law. Section 1983 creates a federal cause of action against those acting under color of state law who violate the Constitution or federal laws.

"76 $118 \mathrm{~S}$ Ct at 2050.

"Schacht $v$ Wisconsin Department of Corrections, 116 F3d 1151, 1153 (7th Cir 1997).

${ }^{78}$ Schacht, 118 S Ct at 2054.

${ }^{79}$ Id at 2054 (Kennedy concurring). 


\section{B. Justice Kennedy's Concurring Opinion}

Justice Kennedy offered two arguments in support of the proposition that removal should constitute consent to federal court jurisdiction. First, he noted that because "[r]emoval requires the consent of all of the defendants,"80 and because the "law usually says a party must accept the consequences of its own acts," ${ }^{81}$ consent to removal is, arguably, a constructive waiver of Eleventh Amendment immunity. ${ }^{82}$ Justice Kennedy buttressed his argument by analogizing removal to other forms of state conduct held to constitute waiver of Eleventh Amendment immunity, such as a state's voluntary intervention in a federal court action to assert its own claim. ${ }^{83}$ Since a state is under no obligation to remove a case and has the unilateral right to block such removal, "any appearance the State makes in federal court may well be regarded as voluntary in the same manner as the appearances which gave rise to the waivers" in voluntary intervention cases. ${ }^{84}$

Justice Kennedy distinguished waiver based on removal from other forms of state action deemed insufficient to constitute consent to federal court jurisdiction. In both Atascadero and Edelman, the Supreme Court affirmed that a state's waiver of its Eleventh Amendment immunity must be unequivocal and that mere participation in a federal program through which the state receives federal funds cannot establish consent to suit in federal court. $^{85}$ In recognition of these decisions, Justice Kennedy noted that a state's consent based on removal amounts "to a direct invocation of the jurisdiction of the federal courts, an act considerably more specific than the general participation in a federal program found insufficient in Atascadero and Edelman."86

Justice Kennedy offered a second argument in support of the proposition that removal by a state should constitute waiver of Eleventh Amendment immunity. He noted that the Supreme Court has held consistently that the Eleventh Amendment bar may be asserted for the first time on appeal, so that a state does

${ }^{30}$ Id.

${ }^{81}$ Id at 2055 (Kennedy concurring).

${ }^{82}$ Id.

s See Gunter v Atlantic Coast Line Railroad Co, 200 US 273, 284 (1906) (holding that "where a State voluntarily becomes a party to a cause and submits its rights for judicial determination, it will be bound thereby and cannot escape the result of its own voluntary act by invoking the prohibitions of the Eleventh Amendment'); Clark $v$ Barnard, 108 US 436, 447-48 (1883) (holding that a state's voluntary intervention in a federal court action to assert its own claim constituted waiver of its Eleventh Amendment immunity).

${ }^{87}$ Schacht, $118 \mathrm{~S}$ Ct at 2056 (Kennedy concurring).

${ }^{25}$ See note 33 and accompanying text.

${ }^{36}$ Schacht, $118 \mathrm{~S}$ Ct at 2057 (Kennedy concurring). 
not waive Eleventh Amendment immunity simply by appearing in federal court and defending on the merits. ${ }^{87}$ Justice Kennedy underscored the "unfairness" that arises from this holding:

In permitting the belated assertion of the Eleventh Amendment bar, we allow States to proceed to judgment without facing any real risk of adverse consequences. Should the State prevail, the plaintiff would be bound by principles of res judicata. If the State were to lose, however, it could void the entire judgement simply by asserting its immunity on appeal. ${ }^{88}$

Permitting states to raise Eleventh Amendment immunity for the first time on appeal affords states an opportunity to await a decision on the merits before committing to the court's jurisdiction.

\section{Why Remedy This "Unfair Advantage"}

Permitting belated assertions of Eleventh Amendment immunity sanctions the practice of using Eleventh Amendment immunity as a tool of strategic litigation. As noted by Justice Kennedy, a state may litigate the merits of a case in federal court without waiving its Eleventh Amendment immunity. ${ }^{89}$ Furthermore, the Eleventh Amendment is not "jurisdictional in the sense that it must be raised and decided by this Court on its own motion." tions to conclude that they are under no duty to address Eleventh Amendment issues unless raised by the parties. ${ }^{91}$ Consequently,

${ }^{87}$ Id at 2055 (Kennedy concurring). In support of this point, see, for example, Florida Department of State $v$ Treasure Salvors, Inc, 458 US 670, 683 n 18 (1982) (plurality opinion) ("The fact that the State appeared and offered defenses on the merits does not foreclose consideration of the Eleventh Amendment issue."); Ford Motor Co v Department of Transportation of Indiana, 323 US 459, 467 (1945) ("The Eleventh Amendment declares a policy and sets forth an explicit limitation on federal judicial power of such compelling force that this Court will consider the issue arising under this Amendment in this case even though urged for the first time in this Court.").

* Schacht, 118 S Ct at 2055 (Kennedy concurring).

${ }^{\infty}$ Id (collecting cases).

${ }^{\infty}$ Patsy $v$ Board of Regents of Florida, 457 US 496, 515 n 19 (1982). See also Schacht, $118 \mathrm{~S} \mathrm{Ct}$ at 2052 ('Nor need a court raise [an Eleventh Amendment] defect on its own. Unless the State raises the matter, a court can ignore it."). This recent affirmation that federal courts are under no duty to raise Eleventh Amendment immunity sua sponte is significant, as some lower courts incorrectly interpreted the Supreme Court's decision in Seminole Tribe as requiring sua sponte consideration of Eleventh Amendment immunity. See Wilson-Jones $v$ Caviness, 99 F3d 203, 206 (6th Cir 1996) (exercising sua sponte review of the Eleventh Amendment issue and finding that Seminole Tribe abrogates footnote 19 in Patsy); In re Fennelly, 212 Bankr 61, 62 n 1 (D NJ 1997) (same).

${ }^{9 t}$ See, for example, Hoffman $v$ Hunt, 126 F3d 575, 582 n 6 (4th Cir 1997) (relying on Patsy to refuse to reach the Eleventh Amendment issue because it was not raised by the parties); Mountain Water Co v Montana Department of Public Service Regulation, 919 F2d 
Eleventh Amendment immunity is often addressed for the first time by appellate courts, and these courts frequently vacate the decisions of lower federal courts because there was no jurisdiction over the state. ${ }^{92}$ As a result, state accountability in federal courts is diminished, as states can easily avoid compliance with unfavorable judgments of federal courts, and private plaintiffs whose resources are limited may be unable to relitigate a meritorious claim in state court.

Essentially, permitting assertions of Eleventh Amendment immunity for the first time on appeal enables a state defendant to condition its grant of federal court jurisdiction over the state on a favorable decision on the merits. Should a federal court render an unfavorable decision, the state may strip that court of its jurisdiction by asserting Eleventh Amendment immunity on appeal. Remedying this unfair advantage would restore the Eleventh Amendment to its proper role as a shield designed to protect state sovereignty..$^{93}$ At the same time, the remedy would ultimately result in greater state accountability, as the merits of a suit would be adjudicated in a court of competent jurisdiction. Should the Supreme Court modify its jurisprudence to eliminate belated assertions of Eleventh Amendment immunity, states would no longer be able to invoke immunity as a tool of strategic litigation, and the values of state sovereignty would be balanced better with those of state accountability.

\section{Eliminating Strategic Assertions of Eleventh Amendment Immunity}

To remedy the unfair advantage enjoyed by states under current law, Justice Kennedy proposed that the Supreme Court treat the Eleventh Amendment as it treats personal jurisdiction. ${ }^{94}$ Accordingly, the Supreme Court could adopt "a rule inferring waiver from the failure to raise the objection at the outset of the proceedings," thereby preventing states from "gaining an unfair ad-

593, $596 \mathrm{n} 1$ (9th Cir 1990) (same); Roberts $v$ College of the Desert, 870 F2d 1411, 1415 (9th Cir 1988) (same); Jane L. v Bangerter, 794 F Supp 1528, 1531 (D Utah 1992) (same).

22 See V-1 Oil Co v Utah State Department of Public Safety, 131 F3d 1415, 1419-22 (10th $\mathrm{Cir}$ 1997) (considering Eleventh Amendment immunity sua sponte and dismissing two claims because jurisdiction over the state entities was found lacking); Suarez Corp Industries v McGraw, 125 F3d 222, 227 (4th Cir 1997) (raising the issue sua sponte and reversing the denial of a motion to dismiss a claim that a state official violated state law); Atlantic Healthcare Benefits Trust $v$ Googins, 2 F3d 1, 4 (2d Cir 1993) (raising the issue sua sponte and dismissing some claims for lack of jurisdiction).

${ }^{3}$ See Part I.C.

s Schacht, $118 \mathrm{~S} \mathrm{Ct}$ at 2055 (Kennedy concurring). 
vantage. ${ }^{95}$ As Justice Kennedy noted, the rule inferring waiver need not apply to cases originally filed in federal court where the state appears and defends itself on the merits. ${ }^{96}$ Rather, such treatment of the Eleventh Amendment could be limited to those cases in which a state, under no compulsion to appear in federal court, voluntarily invokes a federal court's jurisdiction. ${ }^{97}$ Thus, in removal cases, the Court would adopt "a rule of waiver in every case where the State, through its attorneys, consents to removal from the state court to the federal court."198 Justice Kennedy argued that "[i]f the States know or have reason to expect that removal will constitute a waiver, then it is easy enough to presume that an attorney authorized to represent the State can bind it to the jurisdiction of the federal court (for Eleventh Amendment purposes) by the consent to removal." 99

Justice Kennedy's proposed solution suffers from two drawbacks. First, his solution is overinclusive to the extent that it would diminish the Eleventh Amendment protection afforded states by expanding the waiver doctrine. The Supreme Court's jurisprudence wisely interprets states' waiver of sovereign immunity narrowly, requiring an "unequivocal" indication of a state's intent to subject itself to federal court jurisdiction. Under Justice Kennedy's proposed solution, a state's waiver of Eleventh Amendment immunity would be assumed from the act of removal, thereby imputing to a state's attorney not only the authority, but also the intent, to waive the state's sovereign immunity.

Second, Justice Kennedy's solution is underinclusive to the extent that it fails to remedy the problem of strategic assertions of Eleventh Amendment immunity that arises when a suit is originally filed in federal court. In such a case, a state defendant can still await a decision on the merits before committing to the federal court's jurisdiction. Should the federal court issue an unfavorable decision on the merits, the state can appeal the decision, assert Eleventh Amendment immunity for the first time, and force the appellate court to vacate the decision for lack of jurisdiction.

\footnotetext{
${ }^{\infty}$ Id.

${ }^{96}$ Id.

${ }^{87}$ Id at 2055-56 (Kennedy concurring).

* Id at 2056-57 (Kennedy concurring).

${ }^{9}$ Id at 2057 (Kennedy concurring).
} 
1. The threat to state sovereign immunity posed by Justice Kennedy's solution.

Justice Kennedy's proposed solution would constrict the effectiveness of the Eleventh Amendment as a safeguard of state sovereign immunity by expanding the scope of the waiver doctrine, contrary to the trend in the Supreme Court's Eleventh Amendment jurisprudence. ${ }^{100}$ The Court's "reluctance to infer that a State's immunity from suit in the federal courts has been negated stems from recognition of the vital role of the doctrine of sovereign immunity in our federal system." 101 For good reason the Supreme Court has held that it will not infer that a state has consented to suit in federal court in the absence of an explicit waiver. ${ }^{102}$

The Supreme Court's jurisprudence rightly recognizes that states' Eleventh Amendment immunity is protected best by a narrow application of the state waiver doctrine. ${ }^{103}$ Because such immunity is "a guarantee that is implied as an essential component of federalism," 104 the Court endeavors to safeguard it:

Constructive consent is not a doctrine commonly associated with the surrender of constitutional rights, and we see no place for it here. In deciding whether a State has waived its constitutional protection under the Eleventh Amendment, we will find waiver only where stated "by the most express language or by such overwhelming implications from the text as [will] leave no room for any other reasonable construction." 105

By expanding the state waiver doctrine, Justice Kennedy's solution inadequately safeguards state sovereignty. It creates a default rule under which federal courts may infer waiver of Eleventh Amendment immunity unless a state affirmatively objects to federal court jurisdiction. Such a rule forces states to explicitly withhold, rather than explicitly grant, consent to suit in federal court. The default rule in effect would shift from one that preserves states' constitutional right of sovereign immunity to one

\footnotetext{
${ }^{100}$ See id ("It is true as well that the Court's recent cases have disfavored constructive waivers of the Eleventh Amendment and have required the State's consent to suit be unequivocal.").

${ }^{101}$ Pennhurst State School and Hospital v Halderman, 465 US 89, 99 (1984).

${ }^{102}$ See Part I.A.

${ }^{103}$ See text accompanying notes 30-37.

${ }^{104}$ Nevada $v$ Hall, 440 US 410, 430 (1979) (Blackmun dissenting).

${ }^{105}$ Edelman, 415 US at 673, quoting Murray $v$ Wilson Distilling Company, 213 US 151, 171 (1909). See also Atascadero, 473 US at $238 \mathrm{n} 1$.
} 
that assumes forfeiture of that right from the act of removal alone.

Justice Kennedy argues, however, that removal by a state is sufficiently akin to an explicit grant of consent to federal court jurisdiction such that removal should constitute waiver of sovereign immunity. ${ }^{106} \mathrm{He}$ relies on the proposition that "where a State voluntarily become [sic] a party to a cause and submits its rights for judicial determination, it will be bound thereby and cannot escape the result of its own voluntary act by invoking the prohibitions of the Eleventh Amendment." ${ }^{107}$ It is true that the Supreme Court has held that a state's voluntary intervention in a federal court action to assert its own claim is sufficient to constitute waiver of Eleventh Amendment immunity. ${ }^{108}$ Such an inference of waiver involves "an application of the well-accepted principle that when a sovereign sues for affirmative relief, it is deemed to have waived its sovereign immunity as to the issues presented by its affirmative claim." 109 Yet when a state defendant removes a suit to federal court, the state is not asserting an affirmative claim. Rather the state simply is exercising its right as a defendant to choose the forum in which to litigate claims asserted against it.

The distinction between asserting one's own claim as opposed to defending oneself against a claim is a distinction worth preserving when deciding the scope of the waiver doctrine. The distinction preserves a state's right as a defendant to invoke federal court jurisdiction over some claims asserted against it while asserting sovereign immunity with respect to other claims. In Schacht, the Supreme Court noted the very reason why removal by a state defendant differs from a state's voluntary intervention in a federal court case:

[W] here original jurisdiction rests upon the Statute's grant of "arising under" jurisdiction, the Court has assumed that the presence of a potential Eleventh Amendment bar with respect to one claim, has not destroyed original jurisdiction over the case .... A State's proper assertion of an Eleventh Amendment bar after removal means that the federal court cannot hear the barred claim. But that circumstance does not destroy removal jurisdiction over the remaining claims in

\footnotetext{
${ }^{106}$ Schacht, $118 \mathrm{~S} \mathrm{Ct}$ at 2057 (Kennedy concurring).

${ }^{105}$ Id at 2055-56 (Kennedy concurring), quoting Gunter $v$ Atlantic Coast Line Railroad Co, 200 US at 284.

${ }^{108}$ Clark $v$ Barnard, 108 US at 436.

${ }^{100}$ Ford Motor Co, 323 US at 467 n 12.
} 
the case ... A federal court can proceed to hear those other claims. ${ }^{110}$

Accordingly, a state may remove an entire case to federal court and assert Eleventh Amendment immunity with respect to some claims while invoking federal court jurisdiction over others. Treating removal like voluntary intervention would deprive state defendants of the right to invoke federal court jurisdiction over some claims while asserting Eleventh Amendment immunity with respect to others because removal alone would constitute waiver of sovereign immunity.

Justice Kennedy's proposal suffers from an additional problem, as its adoption would entail rejecting the Supreme Court's position that only the state, acting through procedural mechanisms designed to ensure political accountability, can waive Eleventh Amendment immunity. ${ }^{111}$ The Court has held that state officials can waive Eleventh Amendment immunity only if explicitly authorized to do so by the state's constitution or laws. ${ }^{112}$ Thus, under the Court's Eleventh Amendment jurisprudence, removal will constitute waiver only if the official representing the state is granted the explicit authority to waive the state's Eleventh Amendment immunity. ${ }^{113}$ The general authority to represent a state in an action brought against it is not coextensive with the authority to waive the state's Eleventh Amendment immunity. ${ }^{114}$

Under Justice Kennedy's proposal a state's attorney could unilaterally waive a state's sovereign immunity from suit in federal court, even absent explicit authorization from the state itself. ${ }^{115} \mathrm{He}$ suggests that "[i]f the States know or have reason to

\footnotetext{
${ }^{110}$ Schacht, $118 \mathrm{~S} \mathrm{Ct}$ at 2053-54.

"' $\mathrm{S}$ See, for example, Atascadero, 473 US at 241 (collecting cases); Ford Motor Co, 323 US at 467 .

${ }^{112}$ See Ford Motor Co, 323 US at 467-70.

${ }^{13}$ See id at 466-70. See also Estate of Porter $v$ Illinois, 36 F3d 684, 690 (7th Cir 1994) (holding that "state officials can only waive a state's Eleventh Amendment immunity if they are specifically authorized to do so by the state's constitution, statutes, or decisions"); Silver v Baggiano, 804 F2d 1211, 1214 (11th Cir 1986) (holding that "removal by state officials of a suit ... to federal court does not amount to waiver of Eleventh Amendment immunity unless those state officials are authorized to waive such immunity").

${ }^{14}$ See Ford Motor Co, 323 US at 468 ("Nor do we think that any of the general or special powers conferred by statute on the Indiana attorney general to appear and defend actions brought against the state or its officials can be deemed to confer on that officer power to consent to suit against the state in [federal] courts when the state has not consented to be sued."). Various lower federal court decisions have held similarly that a state attorney general cannot waive state sovereign immunity absent explicit authorization. See, for example, Estate of Porter, 36 F3d at 690-91; Silver, 804 F2d at 1214-15; Deseret Water, Oil \& Irrigation Co v California, 202 F 498, 500 (9th Cir 1913).

${ }^{115}$ Schacht, $118 \mathrm{~S} \mathrm{Ct}$ at 2056-57 (Kennedy concurring) ("[T] he absence of specific authorization, it seems to me, is not an insuperable obstacle to adopting a rule of waiver
} 
expect that removal will constitute waiver, then it is easy enough to presume that an attorney authorized to represent the State can bind it to the jurisdiction of the federal court ... by the consent to removal." ${ }^{116}$ But a rule that treats a decision by a state's attorney as equivalent to a decision by the state would confer upon state representatives sovereign powers that only a state (as embodied in its legislature or governor) possesses. Because Justice Kennedy's proposal would transfer sovereign powers to representatives who are not held politically accountable for their decisions, his solution would undermine the principles of federalism and improperly expand the waiver doctrine.

2. Justice Kennedy's solution would not prevent states from using sovereign immunity strategically.

While Justice Kennedy limits his argument to cases where a state removes a suit to federal court, the strategic use of sovereign immunity is not confined to the removal context. Understandably, Justice Kennedy's concurrence focuses on suits originally filed in state court and subsequently removed by a state defendant to federal court, because those were the facts in Schacht. Nevertheless, a state similarly may benefit from belated assertions of sovereign immunity when defending itself against a claim originally filed in federal court. ${ }^{117}$ In such cases, the state may refrain from asserting Eleventh Amendment immunity until the court renders its decision on the merits. If the state prevails, it can take advantage of the claim preclusive effect of its victory. However, should the court render a judgment against the state, the state may assert its immunity for the first time on appeal, causing the case to be dismissed for lack of jurisdiction. ${ }^{18}$ The state thus benefits from the same legal maneuvering irrespective of which party to the suit invoked federal court jurisdiction.

Unlike a state, most private litigants do not have virtually unlimited resources with which to litigate claims. Accordingly, a

in every case where the State, through its attorneys, consents to removal from the state court to the federal court.").

${ }^{116}$ Id at 2057 (Kennedy concurring).

${ }^{\text {"17 }}$ See, for example, Dagnall $v$ Gegenheimer, 631 F2d 1195, 1196 (5th Cir 1980) ("The State has asserted its immunity only after it sought a favorable verdict and lost before the jury. Had it prevailed, Louisiana would doubtless be claiming the case was tried with its consent. That today's decision might permit such an inequity cannot overcome Louisiana's plain constitutional right and clear statutory provision.").

${ }^{118}$ See, for example, Garcia $v$ Board of Education of the Socorro Consolidated School District, 777 F2d 1403, 1405-07 (10th Cir 1985) (vacating a jury verdict in favor of the plaintiff after a state entity raised Eleventh Amendment immunity for the first time on appeal). 
private litigant may be unable to relitigate a meritorious claim in state court should an appellate federal court vacate a favorable judgment due to a state's assertion of Eleventh Amendment immunity. Although the "unfairness" of raising Eleventh Amendment immunity for the first time on appeal seems exacerbated in the removal context, the same unfairness nonetheless exists when a suit is originally filed in federal court and the state awaits a decision on the merits before asserting sovereign immunity. An appropriate solution to the problem of belated assertions of Eleventh Amendment immunity would eliminate the ability of state defendants to behave strategically regardless of how the state finds itself in federal court.

\section{AN ALternative SOlution: REQUIRING FEDERAL COURTS TO CONSIDER ELEVENTH AMENDMENT IMMUNITY SUA SPONTE}

This Part proposes a solution to the problem of strategic assertions of sovereign immunity that better safeguards state sovereignty than the solution proposed by Justice Kennedy. The Supreme Court often treats Eleventh Amendment immunity as a restriction on federal court jurisdiction. However, this treatment is incomplete in that federal courts need not consider the issue of Eleventh Amendment immunity sua sponte. ${ }^{119}$ While the Supreme Court has never committed to a single interpretation of the Eleventh Amendment-in some cases viewing it as an embodiment of sovereign immunity ${ }^{120}$ and in others viewing it as a restriction on federal court subject matter jurisdiction ${ }^{121}$ - the Court invariably acknowledges that the Eleventh Amendment explicitly limits the reach of federal jurisdiction.

As a jurisdictional issue, Eleventh Amendment immunity should be resolved sua sponte at the outset of litigation. Indeed, this is the approach many lower courts already take. ${ }^{122} \mathrm{~A}$ rule that required federal courts to consider the issue of Eleventh Amendment immunity sua sponte would resolve all questions of federal court jurisdiction before the court addressed the merits of

\footnotetext{
${ }^{119}$ Currently, federal courts are permitted, but not required, to consider Eleventh Amendment immunity sua sponte. See note $\mathbf{9 0}$ and accompanying text.

${ }^{120}$ See Part I.A.

${ }^{121}$ See Part III.B.

${ }^{122}$ See, for example, Vinson $v$ Clarke County, 10 F Supp 2d 1282, 1298 n 14 (S D Ala 1998); New England Multi-Unit Housing Laundry Association v Rhode Island Housing and Mortgage Finance Corp, 893 F Supp 1180, 1187 (D RI 1995); Wilkins v Ohio, 885 F Supp 1055, 1066-67 (S D Ohio 1995); Vickery v Jones, 856 F Supp 1313, 1327 (S D Ill 1994); Anheuser-Busch, Inc v Goodman, 724 F Supp 345, 346 (M D Pa 1989); Shipley $v$ First Federal Savings and Loan Association of Delaware, 619 F Supp 421, 434-35 (D Del 1985); In re Fennelly, 212 Bankr 61, 62 (D NJ 1997).
} 
a claim. Under such a rule, whenever a state or state entity appeared before a federal court, the court would, as a preliminary matter, ask the parties to brief the issue of Eleventh Amendment immunity. ${ }^{123}$ The court would then undertake an independent determination of its own jurisdiction, assessing the presence or absence of waiver based on the requirements already established by Eleventh Amendment jurisprudence, such as whether the state legislature authorized federal court jurisdiction in a given case. Consequently, adopting a mandatory sua sponte rule would remedy the problems associated with belated assertions of state immunity without disrupting the Supreme Court's effort to safeguard state sovereignty. ${ }^{124}$

\section{A. The Judicial Power to Consider Arguments Not Raised by the Parties}

"When an issue or claim is properly before the court, the court is not limited to the particular legal theories advanced by the parties, but rather retains the independent power to identify and apply the proper construction of governing law." 125 Nevertheless, a rule mandating sua sponte consideration of Eleventh Amendment immunity is an exceptional remedy for the problem arising from belated assertions of Eleventh Amendment immunity. For good reason, federal courts typically refrain from considering issues not raised by the litigants. As Justice Scalia has noted, "the refusal to consider arguments not raised is a sound prudential practice." 126

Under limited circumstances, however, a court will exercise its power to consider issues not raised by the parties. ${ }^{127}$ The least

\footnotetext{
${ }^{123}$ A rule mandating sua sponte consideration of sovereign immunity would not eliminate all cases in which Eleventh Amendment immunity is asserted for the first time on appeal. There may still be cases in which a defendant is not identified as a state entity at the onset of litigation, and thus, a federal district court may not realize that the suit implicates Eleventh Amendment immunity. Nevertheless, a rule mandating sua sponte consideration of Eleventh Amendment immunity at the outset of litigation would largely eliminate those instances in which sovereign immunity is asserted for the first time on appeal.

${ }^{124}$ It is important to note that in Schacht, the Supreme Court reaffirmed its position that federal courts are not required to consider Eleventh Amendment immunity sua sponte. Schacht, $118 \mathrm{~S} \mathrm{Ct}$ at 2052-53. Nevertheless, this statement is not essential to the Court's holding in Schacht. Furthermore, as this Comment suggests, abandoning this position in order to remedy the problems associated with belated assertions of Eleventh Amendment immunity would disrupt less of the Supreme Court's Eleventh Amendment jurisprudence than the alternative solution proposed by Justice Kennedy. See Part II.D.1.

${ }^{15}$ Kamen $v$ Kemper Financial Services, Inc, 500 US 90, 99 (1991).

${ }^{126}$ United States v Davis, 512 US 452, 464 (1994) (Scalia concurring).

${ }^{127}$ See Eric D. Miller, Comment, Should Courts Consider 18 USC $\$ 3501$ Sua Sponte?, 65 U Chi L Rev 1029, 1039-51 (1998) (examining the main contexts in which courts con-
} 
controversial occasion for sua sponte consideration of legal issues arises when federal courts review subject matter jurisdiction. Federal courts have an obligation to raise jurisdictional defects sua sponte. ${ }^{128}$ This duty arises from the constitutional limitations placed on federal court jurisdiction. Because Article III delineates the cases over which federal jurisdiction extends, ${ }^{129}$ federal courts necessarily are courts of limited jurisdiction. ${ }^{130}$ The parties cannot expand the limited federal judicial power by consenting to a jurisdiction that has not been granted. ${ }^{131}$ Accordingly, federal courts will address jurisdictional defects even if the litigants fail to raise the issue.

\section{B. The Eleventh Amendment as a Jurisdictional Issue: Why Sua Sponte Consideration Should Be Mandatory}

In light of the federal courts' treatment of subject matter jurisdiction, sua sponte review of Eleventh Amendment immunity seems less extraordinary. Eleventh Amendment immunity is often treated as a restriction on federal court subject matter jurisdiction, barring federal courts from hearing suits against state governments. ${ }^{132}$ The text of the Eleventh Amendment supports this view, as the initial language of the Amendment appears to

sider legal issues sua sponte).

${ }^{123}$ See Mount Healthy City School District Board of Education v Doyle, 429 US 274, 278 (1977) (noting that "we are obliged to inquire sua sponte whenever a doubt arises as to the existence of federal jurisdiction"). See also Mansfield, Coldwater \& Lake Michigan Railway Co $v$ Swan, 111 US 379, 382 (1884) (noting the existence of an "inflexible" rule that "without exception" requires the Court, on its own motion, to determine if jurisdiction is lacking).

${ }^{120}$ Article III, § 2, cl 1 states: "The judicial Power shall extend to all Cases, in Law and Equity, arising under this Constitution, the Laws of the United States, and Treaties made, or which shall be made, under their Authority;-to all Cases affecting Ambassadors, other public Ministers and Consuls;- to all Cases of admiralty and maritime Jurisdiction;- - to Controversies to which the United States shall be a Party; - to Controversies between two or more States;- - between a State and Citizens of another State;-between citizens of different States;-between Citizens of the same State claiming Lands under Grants of different States, and between a State, or the Citizens thereof, and foreign States, Citizens or Subjects."

${ }^{130}$ The Supreme Court has noted, "Federal courts are courts of limited jurisdiction. The character of the controversies over which federal judicial authority may extend are delineated in Art. III, $\S 2, \mathrm{cl}$. 1. Jurisdiction of the lower federal courts is further limited to those subjects encompassed within a statutory grant of jurisdiction." Insurance Corp of Ireland, Ltd $v$ Compagnie des Bauxites de Guinee, 456 US 694, 701-02 (1982).

${ }^{131}$ The Supreme Court has held that "no action of [itigants] can confer subject-matter jurisdiction upon a federal court. Thus, the consent of the parties is irrelevant." Id at 702.

${ }^{132}$ See, for example, Pennhurst State School and Hospital v Halderman, 465 US 89, 98 (1984) (holding that "the principle of sovereign immunity is a constitutional limitation on the federal judicial power established in Art. III"). See also Seminole Tribe, 517 US at 68 (quoting Pennhurst). 
express a constitutional limitation on federal subject matter jurisdiction: "The Judicial power of the United States shall not be construed to extend ...."133 The Supreme Court has declared that the Eleventh Amendment "affirm[s] that the fundamental principle of sovereign immunity limits the grant of judicial authority in Art. III." ${ }^{134}$ This interpretation of the Eleventh Amendment as a bar to federal jurisdiction was recently reaffirmed in Seminole Tribe, where the Supreme Court held that "the Eleventh Amendment [stands] for the constitutional principle that state sovereign immunity [limits] the federal courts' jurisdiction under Article III." 135

Because Eleventh Amendment immunity is treated as a jurisdictional issue, sua sponte consideration of this immunity should be mandatory. It is well-established that "[j]urisdiction is power to declare the law, and when it ceases to exist, the only function remaining to the court is that of announcing the fact and dismissing the cause."136 Consequently, federal courts are required to raise objections to subject matter jurisdiction on their own when defects in jurisdiction become apparent. ${ }^{137}$ Eleventh Amendment immunity warrants the same treatment as subject matter jurisdiction. Moreover, because Article III's "case or controversy" requirement counsels against the issuance of decisions that are unlikely to bring about some change or have some effect, ${ }^{138}$ federal courts should be required to resolve any Eleventh Amendment issue before rendering a decision on the merits that is easily vacated on appeal. ${ }^{139}$

Several advantages flow from requiring federal courts to consider Eleventh Amendment immunity sua sponte, in addition to eliminating the problems that arise from strategic assertions of immunity. First, since litigants would brief the issue of Eleventh Amendment immunity, they would be provided with the opportu-

${ }_{100}^{10}$ US Const, Amend XI.

is Pennhurst, 465 US at 98.

${ }^{1 \times 5} 517 \mathrm{US}$ at 64-65.

${ }^{106}$ Ex parte McCardle, 74 US (7 Wall) 506, 514 (1868).

${ }^{135}$ See note 127.

${ }^{13}$ See Hayburn's Case, 2 US (2 Dall) 409 (1792) (recognizing the prohibition on giving advisory opinions). See also $C \& S$ Air Lines, Inc $v$ Waterman Steamship Corp, 333 US 103, 113 (1948) (holding that "[j] udgments within the powers vested in courts by [Article III] may not lawfully be revised, overturned or refused faith and credit by another Department of Government").

${ }^{10}$ For an excellent discussion of the Supreme Court's jurisprudence that counsels against the issuance of opinions by federal courts that are unlikely to bring about change or that are subject to being revised, see James S. Liebman and William F. Ryan, "Some Effectual Power": The Quantity and Quality of Decisionmaking Required of Article III Courts, 98 Colum L Rev 696, 783-810 (1998). 
nity to ensure that the court adequately understood sovereign immunity law as applied to the facts of the case before rendering a decision. Second, a rule mandating sua sponte consideration of Eleventh Amendment immunity actually would conserve judicial resources. Rather than force courts and litigants to expend the resources necessary to adjudicate the merits of a claim simply to have the decision vacated on appeal, sua sponte consideration of Eleventh Amendment immunity would enable a federal court to decide at the outset whether it has jurisdiction before reaching the merits. Finally, because sua sponte consideration of Eleventh Amendment immunity would prevent federal courts from sitting in judgment of states when jurisdiction is lacking, such a rule exhibits judicial restraint.

\section{Implementing a Sua Sponte Rule}

Under a rule that required federal courts to consider the issue of Eleventh Amendment immunity sua sponte, courts would resolve jurisdictional questions before addressing the merits of a claim. When a state or state entity appeared before a federal court, the court would ask the parties to brief the issue of Eleventh Amendment immunity. The court would subsequently undertake an independent determination of its own jurisdiction, assessing the presence or absence of waiver based on the requirements established by Eleventh Amendment jurisprudence. Consequently, adopting a mandatory sua sponte rule would largely eliminate the problems associated with belated assertions of state immunity without disrupting the Supreme Court's effort to safeguard state sovereignty.

A sua sponte rule admittedly introduces new problems to the practice of verifying subject matter jurisdiction. Typically, when federal courts raise jurisdictional defects on their own, they are required to interpret federal law only. For example, when federal courts confirm basic jurisdictional elements, they look to the congressional statutes that establish whether a suit arises under the courts' federal question or diversity jurisdiction. Similarly, when federal courts determine whether a particular case comports with the requirements of Article III jurisdiction, federal courts look to federal precedent, which delineates the bounds of the "case or controversy" requirement.

In contrast, a court considering Eleventh Amendment immunity may be required to interpret state law to determine whether a state's constitution or statutes permit waiver of state immunity in the case at hand. This is because the Supreme Court's treatment of Eleventh Amendment immunity differs from 
the Court's treatment of subject matter jurisdiction in one important respect: while a state may waive its Eleventh Amendment immunity and consent to suit in federal court, ${ }^{140}$ "no action of [the litigants] can confer subject-matter jurisdiction upon a federal court. Thus the consent of the parties is irrelevant."141 Thus, while the Court treats Article III as an absolute limitation on federal courts' jurisdiction, the Court treats the Eleventh Amendment as a "personal privilege which [a state] may waive at pleasure." ${ }^{142}$ Accordingly, when addressing the issue of Eleventh Amendment immunity, a court must determine whether a state's immunity has been waived, a determination that involves the interpretation of state law.

Traditionally, federal courts have preferred to leave the interpretation of state law to state courts. Nevertheless, in suits involving questions of Eleventh Amendment immunity, such restraint is unwarranted. The Supreme Court has held that "[a]lthough a State's general waiver of sovereign immunity may subject it to suit in state court, it is not enough to waive the immunity guaranteed by the Eleventh Amendment."143 Rather, for a state statute or constitutional provision to constitute a waiver of Eleventh Amendment immunity, "it must specify the State's intention to subject itself to suit in federal court."144 Thus, the Court distinguishes between state laws that waive immunity from suit in state court and those that waive immunity from suit in federal court. Only those statutes that address immunity from suit in federal court are relevant to the resolution of Eleventh Amendment immunity. As the Eleventh Amendment holds no relevance to state court jurisdiction, only federal courts will have occasion to address whether a particular state law authorizes waiver of state immunity from suit in federal court. Federal courts are thus the appropriate institutions to interpret state statutes and constitutional provisions directed at state immunity from federal court jurisdiction.

Because a determination of Eleventh Amendment immunity will often require federal courts to interpret state law, such a rule might appear to be burdensome to the courts. In reality, the burden would fall only on the parties. Federal courts that initially raised Eleventh Amendment immunity sua sponte would subse-

\footnotetext{
${ }^{\text {10 }}$ See Pennhurst, 465 US at 99; Hans, 134 US at 20 (noting that a state is immune from suit in federal court "unless the State consents to be sued").

"Insurance Corp of Ireland, 456 US at 702.

${ }^{142}$ Clark v Barnard, 108 US 436, 447 (1883).

${ }^{163}$ Atascadero, 473 US at 241.

${ }^{1+}$ Id.
} 
quently require the parties to brief the issue. The parties would thus identify the relevant state law, and the court would perform its appropriate role of interpreting that law. The fact that many district courts already raise Eleventh Amendment immunity sua sponte ${ }^{145}$ dispels the concern that such a practice is unduly burdensome to federal courts. Yet because other federal courts rely on the Supreme Court's jurisprudence, which permits federal courts to rule on the merits of a suit without first resolving potential Eleventh Amendment objections to the courts' jurisdiction, ${ }^{146}$ Eleventh Amendment immunity is often raised for the first time on appeal. ${ }^{147}$ A rule that would require federal courts to consider Eleventh Amendment immunity on its own motion would eliminate many belated assertions of Eleventh Amendment immunity, conserve limited judicial resources, and restore sovereign immunity to its proper role as a safeguard of state sovereignty.

\section{CONCLUSION}

Allowing a state to raise Eleventh Amendment immunity after a lower federal court has rendered a judgment on the merits gives the state an unfair advantage in litigation. If the state wins in the district court without making an Eleventh Amendment objection, it can exploit the preclusive effect of a favorable judgment on the merits. If the state loses, it can raise the Eleventh Amendment issue on appeal and have the judgment vacated.

Federal courts should be required to raise Eleventh Amendment immunity sua sponte before addressing the merits of a case. Absent an "unequivocal indication" that the state consents to suit in federal court, the federal court lacks jurisdiction over the case. The state may exercise its sovereign power and consent to suit in federal court, so long as its waiver comports with the standards established by the Supreme Court. Because the sua sponte rule would require federal courts to address the issue of Eleventh Amendment immunity at the outset of a case, the rule would prevent states from asserting immunity for the first time on appeal. Consequently, states would no longer be able to use sovereign immunity as a tool of strategic litigation, and the Supreme Court's Eleventh Amendment jurisprudence would better balance the competing values of state accountability and state sovereignty than the current regime.

\footnotetext{
${ }^{14}$ See note 122 and accompanying text.

${ }^{146}$ See note 91 and accompanying text.

${ }^{147}$ See note 92 and accompanying text.
} 